medRxiv preprint doi: https://doi.org/10.1101/2021.05.31.21257712; this version posted June 1, 2021. The copyright holder for this preprint (which was not certified by peer review) is the author/funder, who has granted medRxiv a license to display the preprint in perpetuity.

\title{
Quality of Cervical Cancer Screening at a Family Health Unit in Salvador-BA
}

JULITA MARIA FREITAS COELHO

Faculdade Anísio Teixeira (FAT)

Instituto Federal de Educação da Bahia (IFBA)

Universidade Estadual da Bahia (UNEB)

https://orcid.org/0000-0002-9520-5177

julitamaria@gmail.com

JAMILLY SOUZA DA SILVA

Faculdade Anísio Teixeira (FAT)

https://orcid.org/0000-0002-0722-2365

jamillysouz@hotmail.com

LETÍCIA FONSÊCA SANTOS

Faculdade Anísio Teixeira (FAT)

https://orcid.org/0000-0003-1376-6745

Lfsantos1234@hotmail.com

LYVIA MIRELLE CARNEIRO FRANÇA

Universidade Estadual de Feira de Santana (UEFS)

Secretaria de Saúde do Municipal de Salvador

https://orcid.org/0000-0003-0844-9833

lyvia franca@hotmail.com

GLÁUCIA ALENCAR PONTE

Universidade Estadual de Feira de Santana (UEFS)

Prefeitura Municial de Salvador

https://orcid.org/0000-0003-4606-3595

alencarglaucia@gmail.com

LORENA MOURA DE ASSIS SAMPAIO

Universidade Estadual de Feira de Santana (UEFS)

https://orcid.org/0000-0003-0627-4494

lorenamouraa@hotmail.com

CAROLINE RAMALHO GALVÃO

Universidade Estadual de Feira de Santana(UEFS)

https://orcid.org/0000-0002-5836-7345

galvaokarol@hotmail.com

LORENA RAMALHO GALVÃO

Universidade Estadual de Feira de Santana(UEFS)

https://orcid.org/0000-0002-4643-8994

lore.galvao@hotmail.com

BRUNA MATOS SANTOS DANTAS

Universidade Estadual de Feira de Santana (UEFS)

Faculdade Anísio Teixeira (FAT) 
medRxiv preprint doi: https://doi.org/10.1101/2021.05.31.21257712; this version posted June 1, 2021. The copyright holder for this preprint

(which was not certified by peer review) is the author/funder, who has granted medRxiv a license to display the preprint in perpetuity.

All rights reserved. No reuse allowed without permission.

https://orcid.org/0000-0002-2829-8422

brunamatos.dantas@gmail.com

SARAH DOS SANTOS CONCEIÇÃO

Universidade de Brasília (UNB)

https://orcid.org/0000-0001-5729-1249

sarahs.conceicao@gmail.com

ÉRICA VELASCO DIAS GOMES

Universidade do Estado da Bahia (UNEB)

https://orcid.org/0000-0003-0643-4355

enfa.ericavelasco@gmail.com

MARIA EMÍLIA CIRQUEIRA SILVA

Faculdade Anísio Teixeira (FAT)

https://orcid.org/0000-0002-8556-482X emiliacirqueira@gmail.com

ANA CLARA SILVA OLIVEIRA

Faculdade Anísio Teixeira (FAT)

https://orcid.org/0000-0001-8489-3739

aclaras 1@outlook.com

CAROLINE SANTOS SILVA

Faculdade Anísio Teixeira (FAT)

Universidade Estadual de Feira de Santana (UEFS)

https://orcid.org/0000-0001-5321-3796

s.carolinne5@gmail.com

\begin{abstract}
Introduction: Cytopathological examination is the main method for the screening of cervical cancer, its occurrence can be prevented or minimized through screening, with good coverage, quality of collection and analysis and women's adherence to the examination. Objective: To describe the quality of cytopathological exams performed at a family health unit in Salvador - Bahia during the years 2015 and 2016. Method: A cross-sectional study, of an exploratory descriptive character, was conducted, using a database from a previous study carried out in a health unit in Salvador / BA and approved by the Ethical Committee from State University of Feira de Santana . Results: Preventive gynecological exams of 1,350 women were analyzed, but $330(24.4 \%)$ of them could not be evaluated due to the absence of the report in the health unit and the presence of acellular or hypocellular material that prevented the analysis. From 1020 exams, 45 (3.3\%) presented an unsatisfactory sample, without conditions for analysis, while $589(43.19 \%)$ showed only squamous cells. From $392(29.0 \%)$ reports with an adequate study sample , $150(\%)$ were women with a mean age of 38.49 years. These were located and composed the final sample of the present investigation. Final Considerations: We suggest the need for investments in continuing education for professionals involved in performing cytopathological exams, in order to ensure the right of women to comprehensive and quality health care.
\end{abstract}


medRxiv preprint doi: https://doi.org/10.1101/2021.05.31.21257712; this version posted June 1, 2021. The copyright holder for this preprint (which was not certified by peer review) is the author/funder, who has granted medRxiv a license to display the preprint in perpetuity.

All rights reserved. No reuse allowed without permission.

Keywords: Cervical neoplasms; Cervical cancer screening; Gynecological preventive INTRODUCTION

Cytopathological examination (CE) is the main method for early identification of cervical cancer (CC) and its precursor lesions. Also known as Papanicolau, according to Caetano, Viana e Girianeli (2006), it is recognized as a fast, low cost, and effective for detection, although its vulnerability for collection bias, plate preparation and its interpretation.

Regarding sampling for this assay, its elegibility evaluation has been considered a quality indicator, and the sample that has a representative amount of well distributed, fixed and coloured cells, allowing a diagnostic conclusion, is considered adequate for analysis. The samples may contain squamous, glandular and metaplastic cells (INCA, 2016). On the other hand, samples with an unsatisfactory reading due to technical aspects or cellular sampling leads to an unfeasible diagnosis (BRASIL, 2016).

Most of cervical cancer cases could be prevented by the adherence to cytopathological examination, with a good coverage screening, quality sample collection and correct analysis (GONTIJO et al, 2004). According to the World Health Organization (WHO), with at least $80 \%$ of the population screened, with confirmed diagnosis and adequate therapy, there could be a reduction from 60 to $90 \%$ of cervical cancer cases. Some developed countries show a reduction of CC incidence of $80 \%$ in locations where cytopathological examination was performed with quality and the coverage was reached, and diagnosis was confirmed and adequate therapy was delivered (BRAZIL, 2011).

In order to reduce CC morbidity and mortality in Brazil, the Ministry of Health $(\mathrm{MoH})$ recommends annual examination for sexually active women who are 25 to 64 years old; women younger than 25 years old should avoid this examination. The examination can be performed every three years for women presenting two consecutive normal results, with an interval of one year between them. The first two examinations must be performed annualy, and, if both of results are negative, the next must be taken every three years (BRASIL, 2011; BRASIL, 2016).

Some factors influence on the detection of lesions, such as unsufficient material collection; inadequate smears and plate preparation; technical deficit in 
medRxiv preprint doi: https://doi.org/10.1101/2021.05.31.21257712; this version posted June 1, 2021. The copyright holder for this preprint (which was not certified by peer review) is the author/funder, who has granted medRxiv a license to display the preprint in perpetuity.

All rights reserved. No reuse allowed without permission.

cytopathology laboratories; women's low adherence on being examined (LAPIN et al, 2000). Therefore, the sample analysis can be compromised due to an unsatisfactory collection, invalidating the CE as a screening measure for CC (AMARAL et al., 2008). A false-negative result compromises the patient's prognosis since the non visualization of suggestive lesions of CC may increase its morbimortality (LEITÃO et al, 2008)

Therefore, the conduction of research regarding the quality of $\mathrm{CC}$ screening may offer information that evidence the quality of CE performed, as well as the attainment of parameters to guide strategies to personnel qualification regarding sample collection in CE. The aim of the present study is to describe the quality of cytopathological examinations performed at a Family Health Unity (FHU) in Salvador - Bahia, between 2015 and 2016. .

\section{MATERIAL AND METHODS}

We performed a cross sectional, descriptive and exploratory study, using a database from a previous study. The present study was approved by an Ethical Research Committee (n. 2.548 .705$)$.

The research context was based on a FHU from Salvador county, state of Bahia. Data from patient hospital records and registry from CE collection were analysed between december 2017 and june 2018, in order to identiy potential participants. Subsequently, women located by community health agents were invited to participate in the present research. Women that accepted signed a consent form, and were interviewed with semi-structured questionnaire.

Therefore, women registered in the $\mathrm{FHU}$, presenting $\mathrm{CE}$ results with squamous and glandullar cells, with or without precursor lesion for CC, and with inconclusive results, were selected for the study. According to elegibility criteria, $29 \%$ of women were eligible, and 150 were inclued in the final phase of the study.

Descriptive analysis comprised simple and relative frequencies regarding categorical variables, and central tendency measures for continuous variables. Statistical analyses were performed on Statistical Package for the Social Sciences (SPSS) version 17.0 and STATA version 10.0 softwares.

\section{RESULTS}


Between december 2017 and june 2018, 1,350 cytopathological examinations were performed in San Martin 1 FHU. Nonethless, only 392 reports presented adequate samples, whilst 3.3\% had unsatisfactory sample and $43.19 \%$ showed only squamous cells. We point out that $24.44 \%$ of examinations could not be evaluated because its reports were not available in the health unit, even with a second copy being requested, or did not show a detailed registry (FIGURE 1).

Figure 1 - Quality of oncotic cervical citology samples. Salvador, BA, Brazil $(n=1,350)$

\section{Quality of oncotic cervical citology samples}

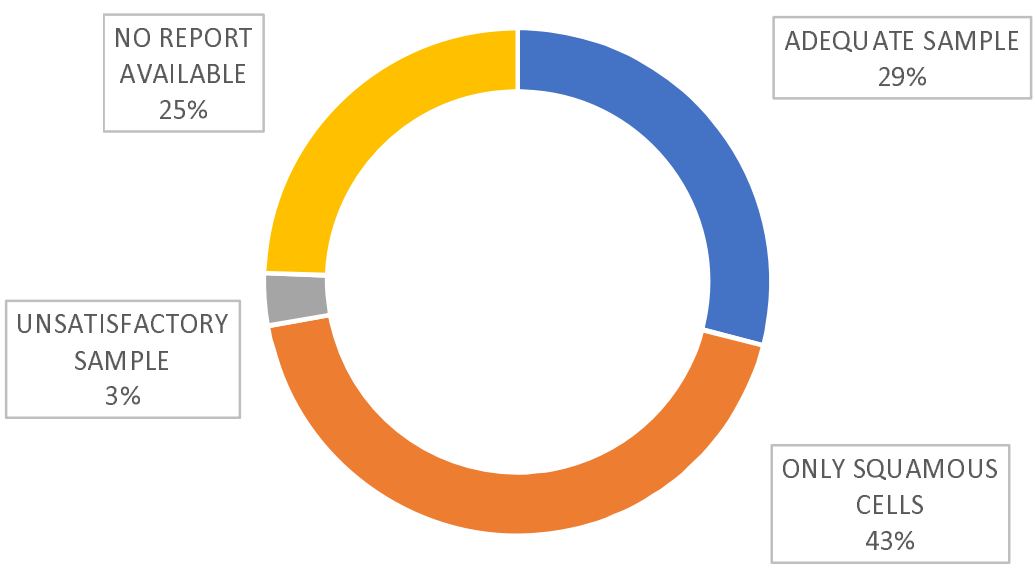

Participants were in average $38.49 \pm 13.68(\%)$ years old (median of 37 years old), and the majority self reported as Black and/or Brown (138/92.0\%). Most part of women in the sample did not have a Professional occupation at the moment of the interview (89/59.3\%) (TABLE 1).

Regarding lifestyle, there was a prevalence of women consuming alcoholic beverages (79/52.7\%), non smokers (142/94.7\%) and with low consumption of ilicit drugs $(n=5 / 3.3 \%)$. We also observed that the majority of women had a low frequency of physical activity (119/79.3\%) (TABLE 1).

Table 1 - Sociodemographic characteristics and lifestyle habits from the studied sample, obtained by the survey form. Salvador, BA, Brazil $(n=150)$. 


\begin{tabular}{|c|c|c|}
\hline Characteristics & $\mathbf{n}$ & $\%$ \\
\hline \multicolumn{3}{|l|}{ Age } \\
\hline Mean & \multirow{2}{*}{\multicolumn{2}{|c|}{$\begin{array}{c}38.49 \pm 13.68 \\
37(18-81)\end{array}$}} \\
\hline Median & & \\
\hline \multicolumn{3}{|l|}{ Race/skin color } \\
\hline White/Yellow/Indigenous & 12 & 8.0 \\
\hline Black/Brown & 138 & 92.0 \\
\hline \multicolumn{3}{|l|}{ Education level } \\
\hline$\geq 8$ years & 95 & 63.3 \\
\hline$<8$ years & 55 & 36.7 \\
\hline \multicolumn{3}{|l|}{ Occupation } \\
\hline Employed & 61 & 40.7 \\
\hline Unemployed & 89 & 59.3 \\
\hline \multicolumn{3}{|l|}{ Smoker } \\
\hline No & 142 & 94.7 \\
\hline Yes & 8 & 5.3 \\
\hline \multicolumn{3}{|l|}{ Alcohol consumption } \\
\hline No & 71 & 47.3 \\
\hline Yes & 79 & 52.7 \\
\hline \multicolumn{3}{|l|}{ Physical activity } \\
\hline$\geq 2$ days/week & 31 & 20.7 \\
\hline 0 to 1 day/week & 119 & 79.3 \\
\hline
\end{tabular}

Results of reproductive conditions show that the majority of women had the first sexual contact up to 18 years old $(102 / 70,0 \%)$, and most of them also referred to relate themselves with up to 4 partners (102/68.0\%), and almost all of them had one fixed partner (149/99.3\%) (TABLE 2).

The majority of women reported more than one year of interval between the last two gynecological preventive examinations (130/86.7\%) and most of them reported using of hormonal contrapectives (86/56.0\%) adequately (135/90.0\%); similarly, most of women reported they did not use other type of contraceptives (98/65.3\%). There were few reports regarding regular (11/7.3\%) and adequate use of condoms (141/94.0\%) (TABLE 2).

Table 2 - Clinical and reproductive conditions and family records of women included in the studied sample, survey form. Salvador, BA, Brazil $(n=150)$.

\section{Characteristics}

\section{Amenorrhea}

No n

$\%$ 


\begin{tabular}{|c|c|c|}
\hline Yes & 72 & 48.0 \\
\hline \multicolumn{3}{|c|}{ First sexual contact } \\
\hline > 18 years old & 45 & 30.0 \\
\hline$\leq 18$ years old & 105 & 70.0 \\
\hline \multicolumn{3}{|c|}{ Number of sexual partners } \\
\hline$\leq 4$ partners & 102 & 68.0 \\
\hline > 4 partners & 48 & 32.0 \\
\hline \multicolumn{3}{|c|}{ Fixed sexual partner } \\
\hline Yes & 149 & 99.3 \\
\hline No & 1 & 0.7 \\
\hline \multicolumn{3}{|l|}{ Misscarriage } \\
\hline None & 101 & 67.3 \\
\hline 1 or more & 49 & 32.7 \\
\hline \multicolumn{3}{|c|}{$\begin{array}{l}\text { Time interval between preventive } \\
\text { examinations }\end{array}$} \\
\hline Less than 1 year & 20 & 13.3 \\
\hline 1 year or more & 130 & 86.7 \\
\hline \multicolumn{3}{|c|}{ Use of hormonal contraceptives } \\
\hline Yes & 84 & 56.0 \\
\hline No & 66 & 44.0 \\
\hline \multicolumn{3}{|c|}{$\begin{array}{l}\text { Adequate use of hormonal } \\
\text { contraceptive }\end{array}$} \\
\hline Yes & 135 & 90.0 \\
\hline No & 15 & 10.0 \\
\hline \multicolumn{3}{|c|}{ Other contraceptive methods } \\
\hline Yes & 52 & 34.7 \\
\hline No & 98 & 65.3 \\
\hline \multicolumn{3}{|c|}{ Regular condom use } \\
\hline Yes & 11 & 7.3 \\
\hline No & 139 & 92.7 \\
\hline \multicolumn{3}{|c|}{ Adequate condom use } \\
\hline Yes & 9 & 6.0 \\
\hline No & 141 & 94.0 \\
\hline \multicolumn{3}{|c|}{ Family record of CC } \\
\hline Yes & 137 & 91.3 \\
\hline No & 13 & 8.7 \\
\hline
\end{tabular}

We observed from cytopathological examination records that only a few part of women showed precursor lesions of CC $(17 / 11,2 \%)$, where the majority of lesions were Atypical Squamous Cells of Undetermined Significance (ASCUS) $(7 / 4,7 \%)$, and the least observed were atypical glandular cells of undetermined significance $(1 / 0,7 \%)$. There was also a low frequency of ASCUS in possibly non neoplasic cells, cannot exclude a high grade intraepithelial lesion (HSIL) $(2 / 1,3 \%)$, of low grade intraepithelial lesion, including human papillomavirus infections, mild dysplasia and intraepithelial cervical neoplasia I (low grade intraepithelial lesion) (5/3,3\%), and high 
grade intraepithelial lesions (intraepithelial cervical neoplasia II and III, in situ carcinoma) (2/1,3\%) (TABLE 3).

Table 3 - Aspects of vaginal microbiota and other gynecological characteristics from cytological vaginal examination from women included in the studied sample. Salvador, BA, Brazil $(n=150)$.

\begin{tabular}{|c|c|c|}
\hline Characteristics & $\mathbf{n}$ & $\%$ \\
\hline \multicolumn{3}{|l|}{ Presence of lesion } \\
\hline No & 133 & 88.7 \\
\hline Yes & 1 & 11.2 \\
\hline \multicolumn{3}{|l|}{ Cellular changes } \\
\hline ASCUS & 7 & 4.7 \\
\hline ASC-H & 2 & 1.3 \\
\hline AGC & 1 & 0.7 \\
\hline LSIL & 5 & 3.3 \\
\hline HSIL & 2 & 1.3 \\
\hline Not applicable & 133 & 88.7 \\
\hline \multicolumn{3}{|c|}{ Atrophy with inflammation } \\
\hline No & 138 & 92.8 \\
\hline Yes & 2 & 8.0 \\
\hline \multicolumn{3}{|l|}{ Vulvar lesion } \\
\hline No & 144 & 96.0 \\
\hline Yes & 6 & 4.0 \\
\hline \multicolumn{3}{|l|}{ Vaginal lesion } \\
\hline No & 149 & 99.3 \\
\hline Yes & 1 & 0.7 \\
\hline \multicolumn{3}{|l|}{ Leukorrhea } \\
\hline No & 67 & 44.7 \\
\hline Yes & 83 & 55.3 \\
\hline \multicolumn{3}{|l|}{ Microbiota } \\
\hline Physiological & 104 & 69.3 \\
\hline Pathological & 46 & 30.7 \\
\hline \multicolumn{3}{|l|}{ Metaplasia } \\
\hline No & 148 & 98.7 \\
\hline Yes & 2 & 1.3 \\
\hline \multicolumn{3}{|l|}{ Benign alterations } \\
\hline Normal & 149 & 99.3 \\
\hline Altered & 1 & 0.7 \\
\hline \multicolumn{3}{|l|}{ Onset of malignancy } \\
\hline Positive & 23 & 15.1 \\
\hline Negative & 127 & 83.6 \\
\hline
\end{tabular}

We also observed the precence of leukorrhea in the most part of examination reports $(83 / 55.3 \%)$; pathological microbiota was less frequent than physiological $(46 / 30.7 \%)$. Metaplasias were rare $(2 / 1.3 \%)$, as well as benign alterations $(1 / 0.7 \%)$; 
medRxiv preprint doi: https://doi.org/10.1101/2021.05.31.21257712; this version posted June 1, 2021. The copyright holder for this preprint (which was not certified by peer review) is the author/funder, who has granted medRxiv a license to display the preprint in perpetuity. All rights reserved. No reuse allowed without permission.

however, positivity for malignancy was more frequent $(23 / 15.1 \%)$ than the two categories cited above (TABLE 3).

\section{DISCUSSION}

Regarding the initial number of examinations evaluated $(n=1,350)$, only $29 \%$ had na adequate collection for diagnosis. Thus, more than 1,000 (71\%) women did not have the opportunity to be screened regarding CC or its precursor lesions. That is because the sample was unsuficcient, unsatisfactory or only had squamous cells, therefore, without conditions for an adequate diagnosis.

Moreover, the examination alterations frequency was $11.2 \%$; therefore, there is a possibility that more than 112 women had these alteratioins at the time of sample collection, but were not diagnosed, or did not receive a control measure or treatment for such alterations, and did not have the right to know their real gynecological health status.

On the other hand, the Brazilian $\mathrm{MoH}$ recommends a minimmum frequency of unsatisfactory samples of $5 \%$ as criteria for quality of collection and sample preservation in the screening examination for CC (BRASIL, 2016). We observed in the present study that the frequency of unsatisfactory samples were according to the Brazilian $\mathrm{MoH}$ recommendation, although values close to zero better indicate an adequate screening (BRASIL, 2012).

In contrast, Santos (2011) showed the elevated frequency of unsatisfactory samples on vaginal cytopathological examinations in Brazilian states. The state of Maranhão had the best evidence for showing a frequency of $5.6 \%$, while Rio Grande do Norte had a frequency of $2.0 \%$. Central-western, Southeast and Southern regions had states with a frequency close to the Brazilian $\mathrm{MoH}$ recommendation. In contrast, in a study performed at Doresópolis, Minas Gerais, all plates (100\%) were considered adequate for cytopathological examination (SILVA; ARAÚJO; ARAÚJO, 2011). Therefore, since sample adequacy is an important indicator of quality in cytopathological examinations (BRASIL, 2016), it is a positive aspect regarding CC screening in the family health unit evaluated in the present study.

This examination is important for the prevention of CC and has a low cost, therefore, the personell qualification is essential and imperative (LEITÃO et al, 2008). 
medRxiv preprint doi: https://doi.org/10.1101/2021.05.31.21257712; this version posted June 1, 2021. The copyright holder for this preprint (which was not certified by peer review) is the author/funder, who has granted medRxiv a license to display the preprint in perpetuity.

This is probably because the big ammount of unsatisfactory samples may be related to personell accuracy during the cytopathological examination.

Adequate cytopaythological examination is mandatory for ensuring women's health, which is a major social right protected by the current legal framework (BRASIL, 1988). Social, political and economic policies focused on the reduction of risk for diseases and harms is a State's responsability. The Unified Health System (Sistema Único de Saúde - SUS) forecasts that access to health must happen in an universal and equitable manner, looking forward to health promotion, protection and recovery (BRASIL, 1990). The above mentioned collection involves mannual work, and, therefore, investments on health professionals qualification is required.

Underpinning with the present study, results from a women's health research, conducted at Aracaju, Sergipe, showed that only $46.2 \%$ (154) of samples were adequate for the analysis. The same study showed that cytopathological examination, cervical oncotic cytolgy test, is considered the best procedure to detect the first lesions, which indicates its systematic undertaking in women who are 25 to 64 years old. Finally, the authors point that social, economic and behavioral factors are associated to examination adherence, therefore, competing for a reduction in survival indicators, when disease is diagnosed in an advanced stage (SILVA et al, 2015).

In contrast, in order to avoid the low frequency of adequate samples, showing squamous and glandular cells, the collection must be representative of the squamocolumnar junction. The presence of endocervical and metaplasic cells in cytopathological smears has been considered as an indicator of collection quality, because it is the main source of pre-neoplasic lesions (UGHINI, 2016). Thus, the squamocolumnar junction is the part with the highest ocurrence of pre-neoplasic lesions, and endocervical and metaplasic cells must be present in samples for cytopathological examination; this works as an indicator for the lack of guidance and training of personell involved in the collection procedures (MONTEIO et al., 2009). Namely, it is possible to consider that the aim of screening for CC from examinations has being unsuccessful, besides the wrong use of public finantial resources and its impact in women's health that failed to obtain information regarding their gynecological condition and possible treatments.

Furthermore, in case of an unsatisfactory result, the patient must redo the examination after a period of six to twelve months, since this timeframe may enable 
medRxiv preprint doi: https://doi.org/10.1101/2021.05.31.21257712; this version posted June 1, 2021. The copyright holder for this preprint

(which was not certified by peer review) is the author/funder, who has granted medRxiv a license to display the preprint in perpetuity.

All rights reserved. No reuse allowed without permission.

early CC diagnosis, and consequently the improvement of therapeutical response, in spite of the burden of the examination recurrence (BRASIL, 2013). This happens as one more disadvantage for the patients, considering that they will have to return to the health unit for a new sample collection for the smears, with possible expenses with displacement, work absence and discomfort at the collection moment. However, this return to the health unit does not happen quite often, and, therefore, these women lose the opportunity of an early diagnosis of possible harms, such as CC. The age range of 25 to 64 years, that predominated in the present study was also found in Aracaju, Sergipe (FERREIRA et al, 2015). These findings respond to the Brazilian $\mathrm{MoH}$, and in this age range, precursor $\mathrm{CC}$ lesions are frequent (BRASIL, 2016). However, it is important to establish a minimal age for this age range.

According to the Brazilian $\mathrm{MoH}$, women with no sexual activity record should not be screened for CC. However, it also points that screening may prevent the majority of cervical neoploasias, through the abnormal alterations identified in cervical cells (pre-neoplasias) (BRASIL, 2016), although these affirmations are contrary to the indication of screening onset at 25 years old. Thus, we understand that these arguments are controversial, favouring the suggestion of anticipating the age of onset of screening examinations.

According to Sasieni et al (2009), the incidence of CC in young women is low, and there are evidence of screening in women younger than 25 yeras old being less efficient than in older women. Similarly, in women younger than 25 years old LSIL are predominant, which regress spontaneously in most cases, and that annual examination does not increase significantly the protective effect of screening. Moreover, the Brazilian $\mathrm{MoH}$ emphasise that examinations out of target age range and recommended peridiocity could overload health services, and compromise access for those that have a precise indication. Namely, indiscriminate screening risk for women up to 24 years old would outweight its possible advantages (BRASIL, 2014; 2016).

Vetrano et al observed that international data showed a percentage of 12 to $45 \%$ of sexually active adolescents that had been screened for CC (VETRANO et al, 2007). Hence, the majority of these women sould have had indication for systematic CC screening, but not because they were young. In this regard, it is possible that many of these women may have precursor lesions, or other women needing treatment, but are not included in the current policies. 
medRxiv preprint doi: https://doi.org/10.1101/2021.05.31.21257712; this version posted June 1, 2021. The copyright holder for this preprint

(which was not certified by peer review) is the author/funder, who has granted medRxiv a license to display the preprint in perpetuity.

All rights reserved. No reuse allowed without permission.

In addition, women that are not screened in the last two appointments show a four time higher risk of CC compared to those screened at the adequate period. Those that were not screened in na early appointment, but lately, also showed na elevated risk. Besides, being screened only with regular results has been associated to a CC from squamous cells risk reduction of $89 \%$, compared to those that were not screened, but only $60 \%$ of reduction to adenocarcinoma (WANG et al, 2020).

Therefore, with the early onset of sexual activities, pregnancy and sexually transmited infections, we understand that this is a highly vulnerable group regarding the future development of CC. A study performed in Sao Paulo showed that on average, the onset of sexual activities happens at 14 years old, in contrast to the Brazilian MoH recommendations (CIRINO et al, 2010). Thus, there is a need for a policy revision regarding women's health, in order to reduce the minimum age recommended for the onset of systematic CC screening, including younger women, for instance those younger than 20 years old.

Accordingly with the present results, the majority of women interviewed in a study in Rio Branco, Acre, were also Brown (89.1\%) and had more than two sexual partners lifelong (70\%) (PRADO et al, 2012). However, considering the social and historical context of Salvador county, the high number of Black/Brown women may not represent the interference of race/color on a higher risk for CC lesions in this sample.

In contrast to the findings from the present study, Borges et al (2012) observed a higher adherence to the preventive examination in those women who practiced physical activity (82.2\%). A higher prevalence of non smokers in the present sample (94.7\%) was also described in Porto Alegre, Rio Grande do Sul (75\%). This low frequency is satisfactory, considering that smoking is a risk factor for CC development (UGHINI, 2016).

We observed a low proportion of vulvar and vaginal lesions in the present sample. Recurrent vulvovaginal infections are very frequent and has social and psicological consequences (NAMARTA et al, 2020). According to Curty et al (2020), in Fortaleza, Ceará, the reasons to cytopathological examinations are related to vulvovaginitis, which represents $70 \%$ of complaints in gynecological consultations (SOOST et al, 1991). However, in the present study, patients looked for examination preventively; that evidences the success of health education iniciatives focused on the present health unit recipients, in spite of inquiries regarding the quality of $\mathrm{CC}$ 
medRxiv preprint doi: https://doi.org/10.1101/2021.05.31.21257712; this version posted June 1, 2021. The copyright holder for this preprint

(which was not certified by peer review) is the author/funder, who has granted medRxiv a license to display the preprint in perpetuity.

All rights reserved. No reuse allowed without permission.

screening, considering weaknesses on sample collections that may contribute to a reliable diagnosis.

Moreover, we also observed in this study a high proportion of women without precursor CC lesions (88.7\%), similarly to results observed by Silva in 2014 (86.8\%). Tipically, we observed a high number of women presenting regular results for the samples analysed. That may indicate that those women that seek for extra health assistance may have their gynecological and reproductive health highly ensured.

Among possible cellular alterations, HSIL are truly precursor CC lesions, given its potential effect on disease progression. Therefore, its detection is considered as main focus of secondary prevention of CC (BRASIL, 2013). The present findings show that only $1.3 \%$ of examinations showed HSIL. However, if all examinations performed in the present study $(n=1350)$ could have had a diagnosis, this proportion would represent a hypotherical number of 18 women with HSIL instead of two. Therefore, 16 women may have developed CC, whether or not they sough for early screening.

Finally, we point for the possible interference of the present sample size on the findings. This raises the need for studies with more robust samples. However, regardless of the sample size, we recognize the waste of public finantial resources on uneffective examinations, low effectiveness on CC screening by primary health care, and the need for higher investments on personell qualification and the revision of current clinical protocols for diagnosis, in order to have a better CC combat. A successfull experience was showed by Jakpbcynski et al, 2018 with personell qualification. They obtained a better sample, representation of required epithelium and examination results.

\section{FINAL CONSIDERATIONS}

The high proportion of unsatisfactory samples described in the present results raises the need for investments on systematic qualification of personell involved in cytopathological examinations. That is relevant considering the identification of women that reported having many partners, therefore, being in higher risk for general gynecological alterations, including cervical cancer. In contrast, it requires additional costs and discomfort on recurrence of examinations, and may impact on the adherence for the systematic disease screening. 
medRxiv preprint doi: https://doi.org/10.1101/2021.05.31.21257712; this version posted June 1, 2021. The copyright holder for this preprint

(which was not certified by peer review) is the author/funder, who has granted medRxiv a license to display the preprint in perpetuity.

All rights reserved. No reuse allowed without permission.

The proportion of unsatisfactory samples in cytopathological examinations is an indicator. It is related to the quality of collection, and also shows the proportion of samples that are considered inadequate or unsufficient for diagnosis, therefore, requiring another examination. Moreover, it allows the evaluation and formulation of qualification of human resources, in order to enhance finantial resources and avoid loss in women's adherence to the examination.

On the other hand, the high frequency of young and sexually active women, that have more than one partner, and with a relatively low use of condoms, is associated with a higher risk for gynecological diseases. Therefore, the current minimal age for cervical cancer screening may be excluding these women. We understand the need for the implementation of protocols, in order to include these women in the screened group, and to standardise the collection and laboratory techniques, and to enhance and to streamline the diagnosis of precursor lesions for this type of cancer. Thus, this is possible if the State acomplish its duty of ensuring women the realization of their fundamental right for health, focusing on prevention and early detection of diseases and possible harms.

Thus, more studies regarding this topic are needed, especially those that explore the adequacy of collection and analysis of cytopathological examination, as an important tool on cervical cancer control, besides the effective prevention of its risk factors, in order to reduce the social and economic impact of this problem.

\section{REFERENCES}

AMARAL R. G.; MANRIQUE, E. J.C.; GUIMARÃES, J. V.; SOUZA, P. J.; MIGNOLI, J. R.Q.; XAVIER, A. P.; OLIVEIRA, A. Influência da adequabilidade da amostra sobre a detecção das lesões precursoras do câncer cervical. Rev Bras Gincecol Obstet. 2008; 30(11):556-60.

BORGES, M.F.de S.O, et al. Prevalência do exame preventivo de câncer do colo do útero em Rio Branco, Acre, Brasil, e fatores associados à não-realização do exame. Caderno de Saúde Pública, v. 28, n. 6, jun, Rio Branco, 2012.

BRASIL. Constituição (1988). Constituição da República Federativa do Brasil. Brasília, DF: Senado Federal: Centro Gráfico, 1988.

. Lei no 8.080, de 19 de setembro de 1990. Lei Orgânica da Saúde. Dispõe sobre as condições para a promoção, proteção e recuperação da saúde, a organização e o funcionamento dos serviços correspondentes e dá outras providências. Brasília, set. 1990. 
medRxiv preprint doi: https://doi.org/10.1101/2021.05.31.21257712; this version posted June 1, 2021. The copyright holder for this preprint (which was not certified by peer review) is the author/funder, who has granted medRxiv a license to display the preprint in perpetuity.

All rights reserved. No reuse allowed without permission.

- Ministério da Saúde. Política Nacional de Atenção Integral à Saúde da Mulher: princípios e diretrizes. 1 ed., 2 reimpr. Brasília: Editora do Ministério da Saúde, 2011.

. Instituto Nacional de Câncer José Alencar Gomes da Silva. Monitoramento das ações de controle dos cânceres do colo do útero e de mama. Informativo Detecção Precoce, v. 3, n. 3, p. 1-12, ago/dez, 2012.

- Ministério da Saúde. Secretaria de Atenção à Saúde. Departamento de Atenção Básica. Controle dos cânceres do colo do útero e da mama / Ministério da Saúde, Secretaria de Atenção à Saúde, Departamento de Atenção Básica. - 2. ed. - Brasília: Editora do Ministério da Saúde, 2013.

- Instituto Nacional de Câncer José Alencar Gomes da Silva. Monitoramento das ações de controle dos cânceres do colo do útero e de mama. Informativo Detecção Precoce, v. 5, n. 1, p. 1-8, jan/abr, 2014.

. Instituto Nacional de Câncer José Alencar Gomes da Silva. Coordenação de Prevenção e Vigilância. Divisão de Detecção Precoce e Apoio à Organização de Rede. Diretrizes brasileiras para o rastreamento do câncer do colo do útero. 2 . ed. rev. atual. - Rio de Janeiro: INCA, 2016.

Ministério da Saúde. ABC do câncer: abordagens básicas para o controle do câncer / Instituto Nacional de Câncer José Alencar Gomes da Silva; organização Mario Jorge Sobreira da Silva. - 3. ed. rev. atual. - Rio de Janeiro: Inca, 2017.

CIRINO, F.M.S.B. et al. Conhecimento, atitude e práticas na prevenção do câncer de colo uterino e hpv em adolescentes. Escola Anna Nery, v. 14, n. 1, p. 126134, Mar., Rio de Janeiro, 2010.

CURTY, G. et al. O papel do microbioma cervicovaginal na gênese e como biomarcador de neoplasia intraepitelial cervical pré-maligna e câncer cervical invasivo. Jornal internacional de ciências moleculares, v. 21, n. 1, p. 222. 2019.

FERREIRA, J.E.L. et al. Perfil da população atendida em um consultório de atendimento integral à saúde da mulher. Ciências Biológicas e da Saúde, v. 3, n. 1, p. 127-140, out., Aracajú, 2015.

GONTIJO, R.C. et al. Avaliação de métodos alternativos a citologia no rastreamento de lesões cervicais: detecção de DNA-HPV e inspeção visual. Rev. Bras. Ginecol. Obstet. v. 26, n. 4, maio, Campinas, 2004.

JAKOBCZYNSKI J, FRIGHETTO M, PERAZZOLI M, DAMBRÓS BP, DALLAZEM B, KIRSCHNICK A. Capacitação dos profissionais de saúde e seu impacto no rastreamento de lesões precursoras do câncer de colo uterino. RBAC. 2018;50(1):80-5.

LAPIN, G. A. DERCHAIN, S. F. M; TAMBASCIA, J. Comparação entre a colpocitologia oncológica de encaminhamento e a gravidade das lesões cervicais intra-epiteliais. Revista de Saúde Publica, v. 34, n. 2, abril, Campinas, 2000. 
medRxiv preprint doi: https://doi.org/10.1101/2021.05.31.21257712; this version posted June 1, 2021. The copyright holder for this preprint (which was not certified by peer review) is the author/funder, who has granted medRxiv a license to display the preprint in perpetuity.

All rights reserved. No reuse allowed without permission.

LEITÃO, N.M.A. et al. Avaliação dos laudos citopatológicos de mulheres atendidas em um serviço de enfermagem ginecológica. Revista Mineira de Enfermagem, v.12, n. 4, out./dez., Ceará, 2008.

NAMARTA, K.; JATINDER S.; MANPREET, KI. Microbiota in vaginal health and pathogenesis of recurrent vulvovaginal infections: a critical review. Ann Clin Microbiol Antimicrob. v. 19, n. 1, jan., 2020.

PRADO, P.R. et al. Caracterização do Perfil das Mulheres com Resultado Citológico ASCUS/AGC, LSIL e HSIL segundo Fatores Sociodemográficos, Epidemiológicos e Reprodutivos em Rio Branco - AC, Brasil. Revista Brasileira de Cancerologia, v. 58, n. 3, p. 471-9, Acre, 2012.

SANTOS, K.M. Distribuição espacial da mortalidade por câncer de colo de útero no Brasil, 1996 a 2009: eco-cuidado de enfermagem. 2011, $110 \mathrm{f}$. Dissertação (Mestrado em Enfermagem) - Universidade Federal do Estado do Rio de Janeiro. Rio de Janeiro, 2011.

SASIENI, P. et al. Effectiveness of cervical screening with age: population based case-control study of prospectively recorded data. British Medical Journal, v. 339, n. 2968, p. 328, 2009.

SILVA, P.V.; ARAÚJO, A.; ARAÚJO, M.R.N. Análise da cobertura do exame citopatológico do colo do útero no município de Doresópolis-MG. Revista de Enfermagem do Centro Oeste Mineiro, v. 1, n. 2, p. 154-163, 2011.

SILVA, M. A. S. et al. Fatores relacionados a não adesão à realização do exame de Papanicolau. Revista Rene, v. 16, n. 4, p. 532-539, 2015.

SOOST, H.J. et al. The validation of cervical cytology: sensitivity, specificity and predictive values. Acta Cytol, v. 35, p. 8-13, 1991.

UGHINI, S.F.O. Importância da qualidade da coleta do exame preventivo para o diagnóstico das neoplasias glandulares endocervicais e endometriais. Departamento de Análises, Universidade Federal do Rio Grande do Sul. Porto Alegre 2016.

VETRANO G, LOMBARDI G, DI LEONE G, PARISI A, SCARDAMAGLIA P, PATE G, et al. Neoplasia intraepitelial cervical: fatores de risco para persistência e recorrência em adolescentes. Eur J Gynaecol Oncol. 2007; 28 (3): 189-92.

WANG, J., ELFSTRÖM, K. M., ANDRAE, B., NORDQVIST KLEPPE, S., PLONER, A., LEI, J., DILLNER, J., SUNDSTRÖM, K., SPARÉN, P. Cervical cancer casecontrol audit: results of the routine evaluation of a national cervical screening program. International Journal of Cancer, v. 146, n. 5, p. 1230-1240, mar., 2020. https://doi.org/10.1002/ijc.32416 